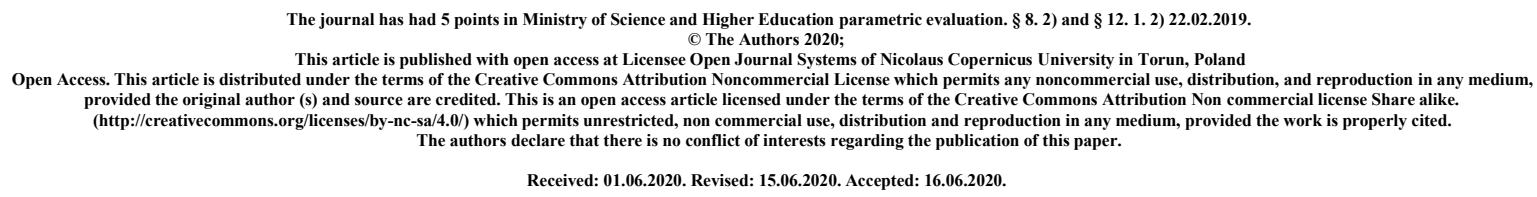

\title{
Zinc detection in cosmetics
}

\section{Jolanta Materna', Barbara Nieradko-Iwanicka ${ }^{2}$}

${ }^{1}$ Students Scientific Association at the Chair and Department of Hygiene Medical University of Lublin orcid https://orcid.org/0000-0002-8910-0870

${ }^{2}$ Chair and Department of Hygiene Medical University of Lublin orcid https://orcid.org/0000$\underline{0002-4839-6003}$

\begin{abstract}
Zinc is a metal which participates in the control of genetic information transfer, protein biosynthesis, affects the proper structure of the skin and hair, has bactericidal activity, accelerates wound healing, increases resistance to infection. It has an effect on skin regeneration and affects collagen metabolism.

The aim of the study was to check it zinc is present in cosmetics.

To detect zinc in cosmetics, $0.2 \mathrm{~g}$ were weighed into a $25 \mathrm{~cm}^{3}$ beaker. $5 \mathrm{~cm}^{3}$ of an $80 \%$ acetic acid solution was added, the beaker was covered with a watch glass and the contents were heated for 5 minutes. The suspension was cooled, poured into a centrifuge tube and centrifuged. The supernatant liquid was poured onto a watch glass, a few drops of $\mathrm{Na}_{2} \mathrm{~S}$ solution were added. The precipitation of the white $\mathrm{ZnS}$ precipitate indicated the presence of zinc in the sample.

105 samples of cosmetics were collected. The compositions of these cosmetics were analyzed. Zinc and its compounds were enumerated by the manufacturers in the composition of 14 cosmetics collected for the study. Presence of zinc was confirmed in Bell HYPOAllergenic Powder, Face palette Bronze'n'blush no 14 and 24, Skin79 Super + Beblesh Balm, MaxFactor - Powder, My Secret - eye shadow, Paese - eye shadow, Ziaja med - soothing treatment, Ziaja GdanSkin - hydrogel face, Tołpa dermo face mask, Mixa - Against imperfections mask, The Ordinary serum, Oriflame Royal Velvet - night cream and BeBeauty Care - face mask.

Conclusion: Zinc was detected in 14 cosmetics.
\end{abstract}

Key words: zinc, cosmetics, detection 
Introduction

Zinc (chemical symbol - Zn) is a metal in the 4th period and 12th group of the periodic table of chemical elements. Its atomic mass is $65,341 \mathrm{u}$, and the atomic number is 30 . The simplified electron configuration is [Ar] $3 \mathrm{~d} 104 \mathrm{~s} 2$. The valence of zinc is II. Occurs at oxidation level 2, creating $\mathrm{Zn} 2+$ ions. It is a chemical element classified as microelement that is needed by the human body in trace amounts. Trace elements act as regulators or catalysts in metabolism, as well as components of body fluids and vitamins [1]. Zinc participates in the control of genetic information transfer, so it consequently participates in the process of protein biosynthesis. In this way, it affects the proper structure of the skin and hair. It is a very reactive element and its salts show bactericidal activity [2]. It accelerates wound healing and increases resistance to infection. It has a significant effect on skin regeneration as it is involved in the processing of fatty acids. In addition, it affects collagen metabolism, is responsible for the proper growth of hair and nails. Its deficiency causes weakening of the skin's immune system, which results in allergies and dermatoses. It is also the cause of nail vitiligo [3]. Zinc deficiency in infants and children may manifest as psoriasis-like skin lesions, while adults most often have skin lesions such as erythema, cracking, pallor, oily skin and impaired wound healing, hair loss and nail fragility [4]. In connection with the above, zinc is a popular ingredient in creams, cosmetic masks, powders, dusting powders, ointments or pastes with anti-inflammatory, astringent and anti-acne effects, which are used to cleanse the skin of accumulated sebum, restore its natural $\mathrm{pH}$, tighten enlarged pores, soothe inflammation [3]. A very common ingredient in cosmetics is zinc oxide $(\mathrm{ZnO})$, which has good adhesive, concealing and sliding properties. It has a drying effect on the skin because it absorbs water well. What's more, this substance comes in the form of a white powder that is used as a white pigment, acting as a physical filter that reflects and disperses UVA and UVB rays. It is also a component of zinc ointment with healing and anti-acne effects [2]. In cosmetics, in which it acts as a dye, it is included in the INCI composition under the name CI 77947. As a protective substance it is allowed in a maximum concentration of $25 \%$ in a ready-to-use preparation. Similarly, zinc oxide in the form of non-particles [5]. Organic cosmetics use zinc salts: acetate, lactate, salicylate and stearate. Inorganic salts like $\mathrm{ZnCl}_{2}$ and $\mathrm{ZnSO}_{4}$ have astringent properties, but irritate the skin. The action of zinc compounds is dangerous and can cause poisoning in the case of oral ingestion, therefore they are not used in the production of lipsticks or toothpastes. They are found in cosmetics intended for external use only [2].

Aim

Due to the potentially numerous possibilities for the use of zinc in cosmetics and the changing regulations on the allowed ingredients of cosmetics, the question arises whether the cosmetic preparations available on the market contain zinc. The research hypothesis was:

Zinc or its compounds are present in low, safe concentrations in cosmetics for use on the skin.

Materials and Methods

To detect zinc in eye shadows and powders, approximately $0.2 \mathrm{~g}$ backfill or eye shadows were weighed into a $25 \mathrm{~cm}^{3}$ beaker. $5 \mathrm{~cm}^{3}$ of an $80 \%$ acetic acid solution was added, the beaker was covered with a watch glass and the contents were heated for 5 minutes. The suspension was cooled, poured into a centrifuge tube and centrifuged. The supernatant liquid was poured onto a watch glass, a few drops of $\mathrm{Na}_{2} \mathrm{~S}$ solution were added. The precipitation of the white $\mathrm{ZnS}$ precipitate indicated the presence of zinc in the sample.

The methodology of the experiment was borrowed from the textbook: Jasiewicz Cz., Baran A. "Guide to lectures and exercises in toxicology" published by the University of Agriculture in Krakow, 2008 [2].

The following reagents were used for the experiment: 
- acetic acid 80\% $\left(\mathrm{CH}_{3} \mathrm{COOH}\right)$ purchased from P.P.H. "STANLAB" Sp. J. (Lublin, Poland); - sodium sulfide 9xhydrate $\left(\mathrm{Na}_{2} \mathrm{~S} \times 9 \mathrm{H}_{2} \mathrm{O}\right)$ purchased from the "HURT-CHEM" Chemical Reagent Metallurgy Plant (Duchnice, Poland), producer of "CHEMPUR" (Piekary Śląskie, Poland);

- methyl alcohol $\left(\mathrm{CH}_{3} \mathrm{OH}\right)$ - solvent for sodium sulfide, purchased at the HURT-CHEM Chemical Rehabilitation Plant (Duchnice, Poland), the producer of "CHEMPUR" (Piekary Śląskie, Poland);

- sulfuric (VI) acid $\left(\mathrm{H}_{2} \mathrm{SO}_{4}\right)$ 95-97\% purchased from Merck (Germany).

The samples were weighed on a laboratory scale MFD by A\&D CO., LTD (made in Korea) with a range of 0.1-200 g; heated on a MONO PH11 electric cooker hob by Eldom Sp. z o.o. (Katowice, Poland); centrifuged using a MIKRO 220 laboratory centrifuge from Hettich (made in Germany) at a speed of 10,000 rpm for 6 minutes.

Results

105 samples of cosmetics collected in the period from June 2019 to February 2020 were prepared for the experiment. The compositions of these cosmetics were analyzed.

Zinc and its compounds were mentioned by the manufacturers in the composition of 14 cosmetics collected for the study. Originally, cosmetics were grouped into makeup powders and eye shadows, in which zinc was expected to be found, and face care cosmetics. The presence of zinc was found in 14 cosmetics, both for makeup and care:

1. Zinc Oxide (nano) (zinc oxide in the form of nanoparticles) - Bell HYPOAllergenic Compact Powder SPF 50 - hypoallergenic compact powder; 02 golden ivory

2. Zinc Oxide - Kobo Professional - Face palette Bronze'n'blush Sculpting - contouring kit; roses No. 24

3. Zinc Oxide - Kobo Professional - Face palette Bronze'n'blush Sculpting - contouring kit; bronzing powder No. 14

4. Zinc Oxide (Zinc Oxide) - Skin79 Super + Beblesh Balm SPF50 + PA +++ Orange vitamin $B B$ cream

5. Zinc Stearate (Zinc Stearate) - MaxFactor - Translucent Professional Loose Powder

6. Zinc Stearate (Zinc Stearate) - My Secret - Natural Beauty, Nude Look - matte eye shadow palette

7. Zinc Myristate (zinc myristate) - Paese - eye shadow palette All About You; shadow night affair

8. Zinc Coceth Sulfate (anionic surfactant from the alkyl sulfate group) - Ziaja med - soothing treatment, soothing and cleansing cream micellar gel for washing the face

9. Saccharomyces / Zinc Ferment (fermented product of yeast Saccharomyces in the presence of zinc) - Ziaja GdanSkin - hydrogel face and body mask

10. Zinc Sulfate - Tołpa dermo face, sebio - exfoliating face-washing mask

11. Zinc Gluconate (Zinc Gluconate) - Mixa - Against imperfections, exfoliating peeling mask without granules 3 in 1

12. Zinc PCA (Proline, 5-oxo-, zinc salt) - The Ordinary - Niacinamide 10\% + Zinc 1\% serum with vitamin $\mathrm{B} 3$ and zinc

13. Zinc Aspartate - Oriflame Royal Velvet - rebuilding night cream

14. Zinc Chloride (zinc chloride) - BeBeauty Care - cleansing and soothing peel-off, face mask

\section{Discussion}

The skin is the largest human organ. It is a physical protective barrier of the body and it performs many key functions necessary for life. Caring for her is important for health reasons, 
as well as for aesthetic reasons. For centuries, both women and men have embellished their bodies, which was associated with various body care and skin treatments, i.e. applying makeup. We are observing the same today. In recent years there has been a dynamic development of the cosmetics industry. Consumers, mainly women, are increasingly interested in skincare and make-up cosmetics, making their choice more and more consciously. Particularly high interest in colored cosmetics. Makeup is for them the opportunity to express themselves, highlight their strengths or develop artistic passion. Undoubtedly, this is an important aspect of their lives. In Japan, a study was conducted to determine whether makeup improves the quality of life for older married couples, both wife and husband, over 60 years of age. The study showed that makeup significantly improved the quality of life of older women, while men did not take advantage of their wives makeup. In wives, the results in the field of physical health, psychological and social relations as well as the general quality of life have been significantly improved thanks to makeup [6]. This study confirms the importance of make-up for women, regardless of their age.

Many vitamins, macro- and microelements affect the proper functioning of the skin and its appendages. One of the key belonging to the latter group is zinc, which is responsible for the proper activity of the skin and mucous membranes. It is an essential nutrient for the growth and development of mammals. In an adult, the daily requirement for this element is $10-15 \mathrm{mg}$, in children $10 \mathrm{mg}$, and in infants 3-5 $\mathrm{mg}$ [7]. This is such an essential element of human health that even a slight deficiency leads to serious problems. It is estimated that around 2 billion people remain at risk of zinc deficiency. This phenomenon is a serious public health problem, including affects a huge number of women and children in India and around the world. Zinc deficiency was a significant etiological factor in the development of juvenile dwarfism in the countries of Central and Eastern Asia [8]. Zn deficit is most dangerous during periods of growth (fetal development and childhood) and during pregnancy in women. Other signs of zinc deficiency include: delayed puberty, secondary hypothyroidism, immune deficiencies, smell and taste disorders, and cognitive impairment [9].

An excess of zinc also has dangerous effects as a deficiency. Zinc enters the body primarily through the digestive and respiratory tracts, and the absorption is low through the skin [10]. Oral administration of zinc compounds is considered to be low toxic [11]. Inhalation exposure occurs mainly in industrial conditions in the form of fumes and dust that contain metallic zinc or zinc oxide [10]. As a result of many years of occupational exposure, respiratory tract irritation, symptoms of "caster fever" (flu-like illness), gastrointestinal disorders and anemia occur. There are also tendencies to inflammation of the upper respiratory tract, tooth decay, excessive sweating [11]. It was believed that prolonged (for weeks to months) exposure to zinc may be indicated by elevated levels of zinc in the hair and nails. However, based on the level of zinc in the hair, the exposure assessment is burdened with an error due to the fact that the amount of zinc in the hair depends on many external factors, such as air pollution, sweat, hair growth rate, distance taken

scalp samples, hair dyeing possible [10]. Zinc may also have neurotoxic effects. Prolonged exposure of cells of the central nervous system to high doses of this element can disturb many metabolic pathways, which in turn contributes to inhibiting the growth and development of neurons or their death. In this way, processes leading to neurodegeneration are induced. Alzheimer's disease is a neurodegenerative disease in which the pathogenesis of cell zinc disorders is of great importance [9]. A study conducted on adult individuals of zebrafish fish exposed to zinc chloride resulted in reduced motor activity and short-term memory impairment, i.e. symptoms similar to Alzheimer's disease [12].

In this work, samples of cosmetics were tested for zinc. Zinc was found in all cosmetics samples, in whose compositions zinc compounds were listed on the packaging. This is demonstrated by the precipitation of white zinc sulfide $(\mathrm{ZnS} \downarrow)$. $\mathrm{ZnS}$ is an insoluble salt [13]. 
$\mathrm{ZnS}$ precipitates in an exchange reaction in which zinc acetate reacts with sodium sulfide. The products of this reaction are insoluble $\mathrm{ZnS}$ and sodium acetate [14]. The scheme of this reaction can be presented as follows:

salt $1+$ salt $2 \rightarrow$ salt $3 \downarrow+$ salt 4

In this case, salt3 is $\mathrm{ZnS} \downarrow$.

The presence of many zinc compounds was found in the tested samples. They were: zinc stearate, zinc myristate, zinc sulfate, zinc gluconate, zinc aspartate and zinc chloride. They perform many functions in cosmetics, including: skin conditioners, astringents, anti-caking agents, viscosity increasing, slip modification, buffering, preserving, cosmetic biocides [15]. These compounds are recognized as safe in cosmetics in current practices of their use. The European Commission limits zinc from water-soluble zinc compounds to a maximum of $1 \%$. In addition, zinc stearate is on the list of dyes allowed in cosmetic products [16]. Zinc oxide ( $\mathrm{ZnO}$, Zinc Oxide) was present in 4 samples. It is a key component of solar filters providing protection against ultraviolet (UV) light [15]. ZnO is a representative of physical (mineral) filters that reflect UV radiation and act as a micro-mirror. Is

considered to be broad-spectrum filter, i.e. protecting against both UVA and UVB. It is called zinc white because it is one of the whitest and most durable mineral pigments, which is why it is widely used in powders, powders and sunscreen [17]. Since Ancient Greece and Rome, hazardous substances such as mercury and lead have been used to obtain a chalky pale complexion, which have penetrated the skin and sometimes led to death. At the time of Elizabeth I, face, neck and cleavage paint was used, the main component of which was lead white, causing hair loss (hence the fashion for high forehead at that time). It was not until the turn of the 19th and 20th centuries that zinc oxide was a good face powder that did not harm the skin [18]. $\mathrm{ZnO}$ has been used in medicine for over 3,000 years for its antiseptic, astringent, antibacterial, anti-inflammatory and healing properties. It is one of the basic active ingredients in preparations, such as Sudocrem, used in therapy and prevention of diaper dermatitis, pressure sores and skin burns [17].

Research indicates that $\mathrm{ZnO}$ is more effective at preventing contact dermatitis in babies compared to talc. In the treatment of diaper dermatitis, it is safe and does not cause side effects, in contrast to creams containing corticosteroids, whose incorrect use may lead to systemic absorption, skin atrophy or Cushing's syndrome [19,20,21]. From the Food and Drug Administration (FDA) review of available animal and human research data and data on physical properties (such as solubility), it appears that transdermal absorption of zinc oxide regardless of particle size - from any topically applied sunscreen formula extremely unlikely. Any de minimis absorption that may occur would not cause adverse health effects, given the high level of endogenous zinc [22]. In 1 of 4 samples tested in this study containing zinc oxide, compact face powder with SPF 50, it was present in the form of nanoparticles (Zinc Oxide (nano)). In accordance with art. 2 of Regulation (EC) No 1223/2009 of the European Parliament and of the Council "nanomaterial means insoluble or biostable and intentionally produced material with at least one dimension

external or internal structure on a scale of 1 to $100 \mathrm{~nm}$ ". Before placing a cosmetic product on the market, the responsible person is obliged to submit to the Commission information on the presence of substances in the form of nanomaterials and a number of other information concerning them, specifically mentioned in Article 16 [5].

Materials at the nano scale can have chemical, physical and biological properties that differ from their chemically identical counterparts, but on a larger scale. Products containing nanomaterials gain an advantage over similar products containing the same materials through features of nanocells such as: improved texture, longer shelf life, improved protection against UV radiation [23]. According to the SCCS opinion of 2012 and the 2013 supplement, zinc oxide in nano form is, under certain conditions, safe for use in sunscreen. Available studies 
show that the nanoparticles have no ability to penetrate the skin. However, a full risk assessment of nanomaterials still requires research [24,25]. Knowledge about the genotoxicity of $\mathrm{ZnO}$ (nano) is still small and the information remains contradictory. A literature review was carried out at the University of Wuerzburg (Germany), which shows that $\mathrm{ZnO}$ nanoparticles can have DNA damaging effects. However, it was emphasized that there is still a lack of studies on long-term exposure to $\mathrm{ZnO}$ nanoparticles that would explain their intracellular bioaccumulation and possible mechanisms of DNA repair and cell survival [26].

Conclusion

Zinc is present in both make-up and face skin care cosmetics.

\section{References}

1. Molski M., Chemia piękna, Warszawa: Wydawnictwo Naukowe PWN; 2012.

2. Jasiewicz C., Baran A., Przewodnik do wykładów i ćwiczeń z toksykologii, Kraków: Wydawnictwo Uniwersytetu Rolniczego w Krakowie; 2008.

3. Szcześniak M., Grimling B., Meler J., Cynk - pierwiastek zdrowia, Farmacja Polska 2014; 70 (7): 363-366.

4. Krajewska J., Cynk (Zn) i jego wpływ na zdrowie człowieka, Lek w Polsce 2015; 25 (1): 58-62.

5. Rozporządzenie Parlamentu Europejskiego i Rady (WE) nr 1223/2009 z dnia 30 listopada 2009 r. dotyczące produktów kosmetycznych (wersja przekształcona) (Tekst mający znaczenie dla EOG) (Dz.U. L 342 z 22.12.2009, s. 59)

6. Shingyoji A., Tokumaru O., Ogata K., Yokoi I., Impact of makeup on quality of life of Japanese married couples: does makeup improve quality of life of wife as well as that of husband?, Gazzetta Medica Italiana - Archivo per le Scienze Mediche 2020; 179 (3): 117-23.

7. Puzanowska-Tarasiewicz H., Kuźmicka L., Tarasiewicz M., Funkcje biologiczne wybranych pierwiastków. III. Cynk - składnik i aktywator enzymów, Pol. Merk. Lek. 2009; XXVII, 161: 419-422.

8. Bhowmik D., Sampath Kumar K.P., A potential medicinal importance of zinc in human health and chronic disease, Int J Pharm Biomed Sci 2010; 1 (1); 05-11.

9. Gapys B., Raszeja-Specht A., Bielarczyk H., Rola cynku w procesach fizjologicznych i patologicznych organizmu, Diagnostyka Laboratoryjna 2014; 50 (1): 45-52.

10. Pakulska D., Czerczak S., Zagrożenia zdrowotne wynikające z narażenia na cynk i jego związki nieorganiczne w przemyśle, Medycyna Pracy 2017; 68 (6): 779-794.

11. Chmielnicka J., Toksyczność metali i półmetali (metaloidów), [In:] Toksykologia współczesna, Ed. Seńczuk W., Warszawa: Wydawnictwo Lekarskie PZWL; 2005: 360-446.

12. Sarasamma S., Audira G., Juniardi S. i wsp., Zinc Chloride Exposure Inhibits Brain Acetylcholine Levels, Produces Neurotoxic Signatures, and Diminishes Memory and Motor Activities in Adult Zebrafish, Interantional Journal of Molecular Sciences 2018, $19,3195$.

13. Gulińska H., Smolińska J., Chemia. Ciekawa chemia, Warszawa: WSiP; 2018.

14. Hars R., Mrzigod A., Mrzigod J., To jest chemia, Warszawa: Nowa Era; 2019.

15. https://cosmeticsinfo.org/ [cited 02.03.2020]

16. Safety Assessment of Zinc Salts as Used in Cosmetics - Final Report, Cosmetic Ingredient Review, September 12, 2018.

17. Adaszyńska-Skwiszyńska M., Tlenek cynku - właściwości i zastosowanie w dermatologii, Terapia 2019; 9 (380): 94-98. 
18. Toedt J., Koza D., Cleef-Toedt K.V., Chemical Composition of Everyday Products, Westport: Greenwood Press; 2005: 33.

19. Stamatas G.N., Tierney N.K.: Diaper dermatitis etiology, manifestations, prevention, and management, Pediatr Dermatol 2014; 3:1-7.

20. Chaithirayanon S., Comparative study between talcum and zinc oxide cream for the prevention of irritant contact diaper dermatitis in infants, J Med Assoc Thai 2006; 99: $1-6$.

21. Baldwin S., Odio M.R., Haines S.L. i wsp., Skin benefits from continuous topical administration of a zinc oxide/petrolatum formulation by a novel disposable diaper, J Eur Acad Dermatol Venereol 2001; 15: 5-11.

22. Sunscreen Drug Products for Over-the-Counter Human Use, A Proposed Rule by the Food and Drug Administration on 02/26/2019, https://www.federalregister.gov/documents/2019/02/26/2019-03019/sunscreen-drugproducts-for-over-the-counter-human-use [cited 26.04.2020]

23. https://cosmeticsinfo.org/nanotechnology [cited 02.03.2020]

24. Opinion On Zinc oxide (nano form) COLIPA S 76, Scientific Committee on Consumer Safety, SCCS/1489/12, Revision of 11 December 2012.

25. Addendum to the Opinion SCCS/1489/12 on Zinc oxide (nano form) COLIPA S76, SCCS/1518/13, Revision of 22 April 2014.

26. Scherzad A., Meyer T., Kleinsasser N., Hackenberg S., Molecular Mechanisms of Zinc Oxide Nanoparticle-Induces Genotoxicity Short Running Title: Genotoxicity of ZnO NPs, Materials 2017, 10, 1427. 